\title{
Broccoli residue-derived nitrogen immobilization following amendments of organic carbon: An incubation study
}

\author{
K. A. Congreves ${ }^{1,2}$, R. P. Voroney ${ }^{1}$, I. P. O'Halloran ${ }^{1,2}$, and L. L. Van Eerd ${ }^{1,2,3}$ \\ ${ }^{1}$ School of Environmental Sciences, University of Guelph, Guelph, Ontario, Canada N1G 2W1; and ${ }^{2}$ Ridgetown \\ Campus, Ridgetown, Ontario, Canada NOP 2CO. Received 13 September 2011, accepted 11 October 2012.
}

\begin{abstract}
Congreves, K. A., Voroney, R. P., O’Halloran, I. P. and Van Eerd, L. L. 2013. Broccoli residue-derived nitrogen immobilization following amendments of organic carbon: An incubation study. Can. J. Soil Sci. 93: 23-31. Cole crops, compared with many other crops, can pose a high risk of $\mathrm{N}$ losses after harvest due to substantial quantities of readily mineralizable $\mathrm{N}$ in crop residues. Organic $\mathrm{C}$ amendments (OCA) may reduce $\mathrm{N}$ losses via immobilization; however, the synchrony of OCA decomposition and cole crop residue $\mathrm{N}$ mineralization is crucial. A soil incubation study evaluated net $\mathrm{N}$ and $\mathrm{C}$ mineralization of broccoli residue-derived $\mathrm{N}$ or fertilizer-derived $\mathrm{N}$ with three OCAs: wheat straw, yard waste, or used cooking oil, to predict $\mathrm{N}$ immobilization and the potential to mitigate post-harvest $\mathrm{N}$ losses. By the 56th $\mathrm{d}$ of incubation, broccoli residue mineralized $67.0 \mathrm{mg} \mathrm{N} \mathrm{kg}^{-1}$. In the broccoli residue-derived $\mathrm{N}$ treatments, wheat straw, yard waste, and used cooking oil significantly reduced the quantity of net $\mathrm{N}$ mineralization by $16.9,12.3$, and $86.0 \mathrm{mg} \mathrm{N} \mathrm{kg}-1$, respectively. The net $\mathrm{N}$ mineralization data were fitted to a first-order exponential model, and the overall trend of OCA was negative, indicating immobilization, whether $\mathrm{N}$ was derived from broccoli residue or fertilizer. The order of effect from OCAs on $\mathrm{N}$ immobilization corresponded to the order of effect on net $\mathrm{C}$ mineralization, where wheat straw and yard waste were lower than used cooking oil. In broccoli residue treatments, compared with fertilizer, higher $\mathrm{N}$ immobilization occurred for used cooking oil, and higher net $\mathrm{C}$ mineralization occurred for used cooking oil and yard waste. The higher $\mathrm{N}$ immobilization and net $\mathrm{C}$ mineralization suggest that broccoli residue produced a synergistic effect on the decomposition of used cooking oil. Additionally, both broccoli residue and used cooking oil treatments had synchronous peaks of net $\mathrm{C}$ mineralization at $4 \mathrm{~d}$. This study provides evidence to warrant field studies to confirm that the application of organic $\mathrm{C}$, especially used cooking oil, after cole crop harvest may be a beneficial management practice to minimize soil $\mathrm{N}$ losses.
\end{abstract}

Key words: Post-harvest, cole crops, wheat straw, yard waste, used cooking oil, nitrogen and carbon dynamics

\begin{abstract}
Congreves, K. A., Voroney, R. P., O'Halloran, I. P. et Van Eerd, L. L. 2013. Immobilisation de l'azote issu des résidus de brocoli après amendement avec du carbone organique : étude d'incubation. Can. J. Soil Sci. 93: 23-31. Comparativement à de nombreuses autres cultures, les crucifères peuvent entraîner une perte considérable de $\mathrm{N}$ après la récolte, car les déchets de culture renferment une importante quantité de $\mathrm{N}$ se minéralisant facilement. Une application de $\mathrm{C}$ organique (ACO) pourrait atténuer ces pertes par immobilisation, cependant, pour cela, il est capital de synchroniser les ACO avec la minéralisation du $\mathrm{N}$ des résidus de crucifères. Les auteurs ont recouru à une étude d'incubation du sol pour évaluer la minéralisation nette du $\mathrm{N}$ et du $\mathrm{C}$ du $\mathrm{N}$ issu des résidus de brocoli ou des engrais, combiné à trois ACO (paille de blé, résidus de jardinage et huile à cuisson usée). L'objectif était de prédire l'immobilisation du $\mathrm{N}$ et la possibilité d'atténuer les pertes de $\mathrm{N}$ après la récolte. Au bout de 56 jours d'incubation, $67,0 \mathrm{mg}$ du $\mathrm{N}$ par kilo des résidus de brocoli avaient été minéralisés. La paille de blé, les résidus de jardinage et l'huile à cuisson usée réduisent significativement la minéralisation nette du $\mathrm{N}$ dérivé des résidus de brocoli (de 16,9, 12,3 et 86,0 $\mathrm{mg}$ de $\mathrm{N}$ par kg, respectivement). Les auteurs ont ajusté les données sur la minéralisation nette du $\mathrm{N}$ avec un modèle exponentiel de premier degré, ce qui a révélé une tendance générale négative pour les ACO, signe qu'il y a immobilisation, que le $\mathrm{N}$ émane des résidus de brocoli ou d'un engrais. L'effet des ACO sur l'immobilisation du N et sur la minéralisation nette du C suit une séquence identique, à savoir l'effet de l'huile à cuisson usée est plus élevé que celui de la paille de blé et des résidus de jardinage. La plus forte immobilisation $\mathrm{du} \mathrm{N}$ et minéralisation nette du $\mathrm{C}$ laisse croire que les résidus de brocoli ont un effet synergique sur la décomposition de l'huile à cuisson usée. De plus, les résidus de brocoli et l'huile de cuisson usée donnent lieu à des pics synchrones pour la minéralisation nette du $C$, après quatre jours d'incubation. Les données venant de cette étude justifient la tenue d'essais sur le terrain en vue de confirmer si l'application de $\mathrm{C}$ organique, principalement sous forme d'huile à cuisson usée, après la récolte des crucifères a un effet bénéfique en minimisant les pertes de $\mathrm{N}$ dans le sol.
\end{abstract}

Mots clés: Post-récolte, crucifères, paille de blé, résidus de jardinage, huile à cuisson usée, dynamique de l'azote et du carbone

Nitrogen amendments are frequently used to enhance crop production yet $\mathrm{N}$ is naturally susceptible to losses via nitrate leaching, denitrification, and ammonia

${ }^{3}$ Corresponding author (e-mail: lvaneerd@uoguelph.ca). volatilization. These losses lead to groundwater and atmosphere contamination, which have a negative impact on the environment. The greatest risk for $\mathrm{N}$ 
losses when producing many vegetable crops may be after harvest, due to the large quantities of $\mathrm{N}$ in the crop residue (Everaarts and De Willigen 1999a; Neetson et al. 1999; Bakker et al. 2009a). While much research has been done to reduce $\mathrm{N}$ losses during the crop growing season (Everaarts 1993; Thompson et al. 2003; Bakker et al. 2009a), there is a need to minimize $\mathrm{N}$ losses during the post-harvest season, when the risk of $\mathrm{N}$ losses is much greater.

Cole crops (Brassica vegetables) in particular, can pose a high risk of $\mathrm{N}$ losses during the post-harvest period, due to the large quantities of readily mineralizable $\mathbf{N}$ in the crop residue. Optimal broccoli yields are obtained with high $\mathrm{N}$ fertilizer rates, such as 270 to $550 \mathrm{~kg} \mathrm{~N}^{-1}$ (Zebarth et al. 1995; Everaarts and De Willigen 1999b; Thompson et al. 2002; Yoldas et al. 2008; Bakker et al. 2009b). Thus applications of 400 to $500 \mathrm{~kg} \mathrm{~N} \mathrm{ha}{ }^{-1}$ are not atypical by growers. Broccoli plants accumulate large quantities of $\mathrm{N}$, up to as much as 320 and $401 \mathrm{~kg} \mathrm{~N} \mathrm{ha}^{-1}$ in above-ground biomass with optimal $\mathrm{N}$ fertilizer rates (Thompson et al. 2002; Bakker et al. 2009a), consequently leaving $\approx 100$ to 330 $\mathrm{kg} \mathrm{N} \mathrm{ha}{ }^{-1}$ in the field as crop residue or soil mineral $\mathrm{N}$ (SMN) (Everaarts and De Willigen 1999a; Bakker et al. 2009a). Potential post-harvest mineral $\mathrm{N}$ losses appear to be more related to crop residue $\mathrm{N}$ rather than $\mathrm{N}$ fertilizer remaining in the soil, as SMN at broccoli harvest typically ranges from 4 to $7 \mathrm{mg} \mathrm{N} \mathrm{kg}^{-1}$ in the top $30 \mathrm{~cm}$ depth with $\mathrm{N}$ fertilizer rates from 0 to $450 \mathrm{~kg}$ $\mathrm{N} \mathrm{ha}^{-1}$ (Bakker et al. 2009a). Additionally, Everaarts and De Willigen (1999a) reported mineral N concentrations of 12 to $34 \mathrm{~kg} \mathrm{~N} \mathrm{ha}^{-1}$ in $0-60 \mathrm{~cm}$ depth at harvest after the optimum banded $\mathrm{N}$ application $(270 \mathrm{~kg} \mathrm{~N}$ $\mathrm{ha}^{-1}$ ). Broccoli residue decomposition results in rapid $\mathrm{N}$ mineralization, which fits a first-order kinetics model and releases $\approx 35$ to $60 \%$ of total $\mathrm{N}$ in broccoli residue (De Neve and Hofman 1996). Thus, based on the 35 to $60 \% \mathrm{~N}$ release of broccoli residue (containing 100 to $330 \mathrm{~kg} \mathrm{~N} \mathrm{ha}^{-1}$ ), it is estimated that 35 to $198 \mathrm{~kg} \mathrm{~N}^{-1}$ would be mineralized after harvest. Considering that the quantity of SMN is directly related to the vulnerability to $\mathrm{N}$ losses (Addiscott et al. 1991), broccoli residue poses a significant risk of $\mathrm{N}$ losses during post-harvest period due to the large quantity of mineralizable $\mathrm{N}$.

A management practice of amending soil with organic $\mathrm{C}$ has the potential to immobilize $\mathrm{N}$, thereby minimize $\mathrm{N}$ losses in agricultural systems. By redirecting organic $\mathrm{C}$ materials from waste streams, a new sustainable method of utilizing these materials may be developed. Research has demonstrated OCAs of wheat straw (Jawson and Elliot 1986; Mary et al. 1996; Bending and Turner 1999; Henriksen and Breland 1999), yard waste (Hartz and Giannini 1998; Amlinger et al. 2003; Claassen and Carey 2004), and oily food waste (Plante and Voroney 1998; Rashid and Voroney 2003, 2004) reduced $\mathrm{SMN}$ levels via $\mathrm{N}$ immobilization. In the aforementioned studies, immobilized $\mathrm{N}$ was derived from fertilizers or indigenous SMN. There is potential to immobilize $\mathrm{N}$ derived from crop residue with the addition of organic $\mathrm{C}$; however, the timing and rate of crop residue $\mathrm{N}$ mineralization relative to organic $\mathrm{C}$ decomposition will affect the mineral $\mathrm{N}$ dynamics. Co-application of a high $\mathrm{N}$ crop residue (groundnut) with a high carbon crop residue (rice straw) has been shown to reduce $\mathrm{N}$ losses (Kaewpradit et al. 2009).

The application of organic $\mathrm{C}$ with broccoli residue has not been investigated. The decomposition rates for broccoli residue alone, broccoli residue-derived $\mathrm{N}$ with organic $\mathrm{C}$, and fertilizer-derived $\mathrm{N}$ with organic $\mathrm{C}$ must be investigated to assess the effectiveness of reducing SMN levels after broccoli harvest. Therefore, the objectives of this study were to evaluate the effects of three different OCAs (wheat straw, yard waste, and used cooking oil) on $\mathrm{N}$ dynamics ( $\mathrm{N}$ mineralization) and microbial activity (C mineralization) under controlled laboratory conditions, when the source of $\mathrm{N}$ was derived from broccoli residue or fertilizer. This research could lead to the development of best management practices for more sustainable cole crop production by minimizing post-harvest soil $\mathrm{N}$ losses.

\section{MATERIALS AND METHODS}

Brookston clay loam (Orthic Humic Gleysol) soil from Ridgetown, Ontario, previously cropped to broccoli (Brassica oleracea L. var. italica cv. 'Ironman') was collected from $0-15 \mathrm{~cm}$ depth at harvest in 2010. Soil characteristics were evaluated according to Carter and Gregorich (2008), which included $\mathrm{pH}$ (1:1 vol $\mathrm{vol}^{-1}$ method), organic matter (modified Walkley Black method), $\mathrm{N}(\mathrm{KCl}$ extraction and colorimetric analysis method), P (Olsen bicarbonate extraction method), Ca, $\mathrm{K}, \mathrm{Mg}$ (atomic absorption via ammonium acetate extraction), cation exchange capacity (estimated based on ammonium acetate extraction and $\mathrm{pH}$ ), and soil texture (hydrometer method). The soil used in microcosms had a $\mathrm{pH}$ of $5.2,28000 \mathrm{mg}$ of organic matter $\mathrm{kg}^{-1}, 9.5 \mathrm{mg} \mathrm{N} \mathrm{kg}^{-1}, 35 \mathrm{mg} \mathrm{P} \mathrm{kg}^{-1}, 66 \mathrm{mg} \mathrm{K} \mathrm{kg}^{-1}$, $128 \mathrm{mg} \mathrm{Mg} \mathrm{kg}{ }^{-1}, 1984 \mathrm{mg} \mathrm{Ca} \mathrm{kg}{ }^{-1}$, cation exchange capacity of $20.8 \mathrm{cmol} \mathrm{kg}-1,58 \%$ sand, $18 \%$ silt, and $24 \%$ clay. Visible roots were removed from the soil sample by hand-picking and passing the soil through a 5 -mm screen. The soil was dried at $60^{\circ} \mathrm{C}$ for moisture content determination and preparation for the incubation study.

After harvest, eight broccoli plants (head removed, stem and leaves intact) were collected from the field. Intact plants were oven dried at $60^{\circ} \mathrm{C}$ for moisture content determination and preparation for the incubation study, and dried tissue was hand chopped to $<1 \mathrm{~cm}^{2}$. Broccoli stem pieces that were too tough to chop by hand were ground using a Wiley Mill (Thomas Scientific, Swedesboro, NJ) with a 2-mm- diameter opening screen mesh. Broccoli stem and leaf pieces were homogenized prior to the addition to soil.

The OCAs included locally sourced (Ridgetown, Ontario): recently harvested wheat straw, municipal 
yard waste, and restaurant used vegetable cooking oil. Solid OCAs were oven dried at $60^{\circ} \mathrm{C}$ for moisture content determination, and hand chopped to approximately $<1 \mathrm{~cm}^{2}$ for use in the incubation study. The used cooking oil was mixed thoroughly prior to application to soil. The $\mathrm{C}: \mathrm{N}$ ratios and $\mathrm{N}$ content of broccoli residue and OCAs (Table 1) were determined by dry combustion (Rutherford et al. 2008), using a LECO CN analyzer (Leco Corporation, St. Joseph, MI).

\section{Nitrogen Mineralization}

For the $\mathrm{N}$ mineralization trial, a randomized complete block design was established with the experimental units randomized within four replications in each of eight time blocks, for destructive sampling of microcosms. The microcosms were set up in $250 \mathrm{~mL}$ glass jars each containing $60.0 \mathrm{~g}$ of dry soil. The soil was adjusted to $40 \%$ water holding capacity, as estimated by soil texture (Saxton et al. 1986), by adding $7.20 \mathrm{~mL}$ distilled water to each jar, and pre-incubated for $3 \mathrm{~d}$ before any amendments were added. The broccoli residue-derived $\mathrm{N}$ treatments included: an unamended control, a control of $268 \mathrm{mg}$ of dry broccoli residue (without any other amendments), and $268 \mathrm{mg}$ of dry broccoli residue + each OCA (separate OCA treatments with weights equivalent to $207 \mathrm{mg}$ of fresh weight, thus a dry weight of $177 \mathrm{mg}$ of wheat straw, $157 \mathrm{mg}$ of yard waste, and a fresh weight of $207 \mathrm{mg}$ for used cooking oil). Additionally, fertilizerderived $\mathrm{N}$ treatments were established to serve for comparison to the broccoli residue-derived $\mathrm{N}$ treatments. In incubation studies, mineral $\mathrm{N}$ is typically added to establish sufficient SMN levels for microbial decomposition, such as in Rashid and Voroney (2004). Thus, to investigate the timing of broccoli residue $\mathrm{N}$ mineralization in relation to the microbial $\mathrm{N}$ requirement for organic $\mathrm{C}$ decomposition, the fertilizer-derived $\mathrm{N}$ treatments included: fertilizer only (with $34 \mathrm{mg}$ of $\mathrm{NH}_{4} \mathrm{NO}_{3}$ ), $268 \mathrm{mg}$ of dry broccoli residue $+34 \mathrm{mg}$ of $\mathrm{NH}_{4} \mathrm{NO}_{3}$, and $34 \mathrm{mg}$ of $\mathrm{NH}_{4} \mathrm{NO}_{3}+$ each OCA, at the respective, aforementioned rate.

The rate of broccoli crop residue application corresponds to $60 \mathrm{Mg} \mathrm{ha}^{-1}$ fresh crop residue, a rate representative of field broccoli residue (Bakker et al. 2009a) yet greater than used in previous laboratory research (De Neve et al. 1996). The rate of OCA corresponds to a field application rate of $5 \mathrm{Mg} \mathrm{ha}^{-1}$ fresh organic carbon material and within the recommendations set by Rashid

\begin{tabular}{|c|c|c|}
\hline Amendment & $\mathrm{C}: \mathrm{N}$ ratio & $\mathrm{N}$ content ( $\mathrm{mg} \mathrm{kg}^{-1}$ dry matter) \\
\hline Broccoli residue & $10: 1$ & 39000 \\
\hline Wheat straw & $61: 1$ & 7000 \\
\hline Yard waste & $52: 1$ & 6000 \\
\hline Used cooking oil & $>1000: 1$ & 400 \\
\hline
\end{tabular}

${ }^{\mathbf{z}}$ Dry matter for solid materials and as-is for used cooking oil. and Voroney (2004) for used cooking oil. The amounts of wheat straw, yard waste, and used cooking oil can be expressed as quantities of added $\mathrm{C}$, with $\mathrm{C}$ loading rates of 1.2, 0.9 , and $1.5 \mathrm{~g} \mathrm{C} \mathrm{kg}^{-1}$ soil, respectively, and reflect a practical application rate at a field scale. The quantity of $\mathrm{NH}_{4} \mathrm{NO}_{3}$ fertilizer added to attain sufficient levels of $\mathrm{SMN}$ was the calculated microbial $\mathrm{N}$ requirement $(50 \mathrm{mg}$ $\mathrm{N} \mathrm{kg}^{-1}$ ) for total decomposition of the broccoli residue, based on a microbial $\mathrm{C}: \mathrm{N}$ ratio of $8: 1$, a $\mathrm{C}$ assimilation of one-third added $\mathrm{C}$, an average $\mathrm{C}$ loading rate of $1.2 \mathrm{~g} \mathrm{C} \mathrm{kg}^{-1}$ soil, and assuming negligible $\mathrm{N}$ will be supplied by OCAs.

At the incubation time zero (which was $3 \mathrm{~d}$ after soil wetting and pre-incubation), soil and amendments were mixed thoroughly to ensure homogeneity before the jars were closed with perforated gas-permeable Parafilm to minimize water loss. The microcosms were incubated in the dark, at room temperature $\left(22 \pm 3^{\circ} \mathrm{C}\right)$. The jars were weighed weekly to assess moisture loss; distilled water was added approximately every $2 \mathrm{wk}$ to maintain soil moisture.

The microcosms were destructively sampled by removing four replicates of each treatment in one time block on $1,3,7,14,21,28,42$, and 56 d. Soil $\mathrm{NO}_{3}^{-}-\mathrm{N}$ and $\mathrm{NH}_{4}^{+}-\mathrm{N}$ were quantified using the Maynard et al. (2008) method, briefly, $5 \mathrm{~g}$ of soil was extracted with $25 \mathrm{~mL}$ of $2 \mathrm{M} \mathrm{KCl}$, shaken for $30 \mathrm{~min}$, filtered and analyzed colorimetrically on an AutoAnalyzer3 (SEAL Analytical Inc., Mequon, WI) with a high-resolution digital colorimeter to quantify $\mathrm{NH}_{4}^{+}-\mathrm{N}$ (method G-102) and $\mathrm{NO}_{3}^{-}-\mathrm{N}$ (method G-200). Nitrogen mineralization was expressed as a value in $\mathrm{mg} \mathrm{N} \mathrm{kg}^{-1}$ soil. Net $\mathrm{N}$ mineralization of: (i) broccoli residue alone treatment was estimated as the difference of SMN in the broccoli residue alone and SMN in the unamended treatment, (ii) broccoli residue-derived $\mathrm{N}$ with OCA was estimated as the difference of SMN in broccoli residue-derived $\mathrm{N}$ with OCA and SMN in the unamended treatment, (iii) fertilizer-derived $\mathrm{N}$ with OCA (or broccoli residue) treatments was estimated as the difference of SMN of fertilizer-derived $\mathrm{N}$ with OCA (or broccoli residue) treatments and SMN in fertilizer alone treatment.

\section{Carbon Mineralization}

The design of the $\mathrm{C}$ mineralization trial was a randomized complete block with four replications. The treatments, soil quantity, and amendment weights were the same as the $\mathrm{N}$ mineralization trial. To ensure good aeration, soil was placed in a $250-\mathrm{mL}$ volume container made of $1-\mathrm{mm}^{2}$ mesh screen aluminum, and sealed inside a 2-L glass jar. In each jar was a vial containing $20 \mathrm{~mL}$ of $1 \mathrm{M} \mathrm{NaOH}$ to trap evolved $\mathrm{CO}_{2}$, and a $20-\mathrm{mL}$ vial of distilled water to maintain soil moisture. A set of two sealed 2-L jars with only $\mathrm{NaOH}$ and water vials were included to quantify background $\mathrm{CO}_{2}$ levels. All microcosms were incubated in the dark at $22 \pm 3^{\circ} \mathrm{C}$.

Non-destructive sampling occurred on 2, 4, 7, 10, 13, 17, 22, 28, 35, 42 and $56 \mathrm{~d}$. Evolved $\mathrm{CO}_{2}$ was determined 
by back-titrating $\mathrm{NaOH}$ with $0.5 \mathrm{M} \mathrm{HCl}$ using a phenolphthalein indicator, after the addition of $2 \mathrm{~mL}$ $1 \mathrm{M} \mathrm{BaCl}_{2}$. At each sampling day, the jars were opened for 30 to 60 min before replacing the $\mathrm{NaOH}$ traps and resealing the jar. Net $\mathrm{C}$ mineralization was expressed as a cumulative value in $\mathrm{mg} \mathrm{C} \mathrm{kg}^{-1}$ soil, as well as a rate of $\mathrm{mg} \mathrm{C} \mathrm{kg}^{-1}$ soil $\mathrm{d}^{-1}$. Net $\mathrm{C}$ mineralization was calculated in the same method as described for net $\mathrm{N}$ mineralization.

\section{Statistical Analyses}

The analyses were conducted with the PROC MIXED method in SAS (SAS Institute, Inc., version 9.2, Cary, $\mathrm{NC}$ ). The net $\mathrm{N}$ mineralization data were subjected to an analysis of variance with fixed effects of treatment, incubation day, and treatment $\times$ incubation day interaction. Random effect was block(incubation day). The assumptions of a variance analysis were that model effects were additive and the errors were random, independent, normally distributed, mean of zero, and homogeneous. Assumptions were tested by plotting residuals of predicted by fixed effects and assessing normality with a Shapiro-Wilk test (Bowley 2008). The presence of outliers was tested by comparing studentized residuals to Lund's critical value (Bowley 2008). Treatment $\times$ incubation day interaction was partitioned into simple effects of treatment at the incubation day level of $56 \mathrm{~d}$ (final day) with an LSD test, and regression contrasts with an F-test. Significance was determined with a type 1 error rate of 0.05 . A non-linear regression for a first order exponential model $y=A\left(1-\exp ^{-k(t)}\right)$ ( $y=$ net $\mathrm{SMN}, A=$ coefficient indicates amount of mineralizable $\mathrm{N}$ at $1 \mathrm{~d}, k=$ rate constant, $t=$ incubation day) was fitted to the net $\mathrm{N}$ mineralization data and equation coefficients were determined with PROC NLIN. The net $\mathrm{C}$ mineralization and $\mathrm{C}$ mineralization rate data were subjected to a repeated measures analysis of variance with fixed effects of treatment, incubation day, and treatment $\times$ incubation day interaction. Random effect was block. The same assumptions of an analysis of variance were tested, as described above. Repeated measures analysis was conducted with treatment $\times$ block as the subject. The model included the generalized Kenward-Roger correction to compute denominator degrees of freedom (Littell et al. 2002). The default covariance structure of response variable was chosen, to render convergence of the complex model. To assess the predictive strength of a logistic regression, Efron's Pseudo $R^{2}$ (Efron 1978) was computed as the square of the correlation between the predicted and observed values. Net $\mathrm{C}$ mineralization rate data were partitioned into simple effects of treatment $4 \mathrm{~d}$ (peak) with an LSD test, and net $\mathrm{C}$ mineralization data were partitioned into simple effects of treatment $56 \mathrm{~d}$ (final day) with an LSD test. Significance was determined with a type 1 error rate of 0.05 .

\section{RESULTS AND DISCUSSION}

\section{Mineral Nitrogen Concentrations}

In the unamended control, SMN was $37.5 \mathrm{mg} \mathrm{N} \mathrm{kg}^{-1}$ (4 d after rewetting) and continued to increase throughout the study. Numerous studies have found a SMN flush after re-wetting soil which was oven-dried (Birch 1959; Blagodatsky and Yevdokimov 1998). A mineral N spike can be attributed to the drying of soil which disturbs microbial biomass, causes cellular lysis, and consequently a release of $\mathrm{N}$ from microbial biomass (Hans-Werner et al. 2004), or $\mathrm{N}$ mineralization of broccoli roots. Thus, the flush of SMN on day 1 of the incubation in the unamended control observed in the present study was likely a reflection of soil drying prior to the experiment. Hence, all data were presented as net mineralization.

Throughout the time course, $\mathrm{NH}_{4}^{+}-\mathrm{N}$ levels were higher than expected (an average of $56 \%$ of $\mathrm{SMN}$ ) considering that $\mathrm{NH}_{4}^{+}$is usually rapidly converted to $\mathrm{NO}_{3}^{-}$in most agricultural soils (Norton 2008). The apparent low nitrifying activity was likely attributed to soil drying at $60^{\circ} \mathrm{C}$ prior to the experiment, as well as the soil $\mathrm{pH}$ of 5.2. High soil temperatures $\left(>35^{\circ} \mathrm{C}\right)$ can slow nitrifying activity (Myers 1975; Hasson et al. 1987), and intermediate temperatures $\left(15\right.$ to $\left.25^{\circ} \mathrm{C}\right)$ have resulted in maximum nitrification (Avrahami et al. 2003). However, some differential responses of soil organisms after heating had led to the suggestion that chemoautotrophic nitrifiers may be less sensitive to heat than once believed (Hart et al. 2005). Bartlett and James (1980) acknowledge that oven-drying soil can be most convenient for laboratory practices, and soil may be re-moistened for a period prior to use. Fu et al. (1987) also found significant $\mathrm{NH}_{4}^{+}$levels during $12 \mathrm{wk}$ of incubation in one soil at $\mathrm{pH}$ 4. The relatively low soil $\mathrm{pH}$ (5.2) in the present study may have inhibited nitrification, as it generally slows below pH 6 (Paul and Clark 1996). Similarly, a sharp rise in $\mathrm{NH}_{4}^{+}$concentration has been observed in dried and re-wetted acidic soils ( $\mathrm{pH} 4.45)$, with a slow recovery of nitrifying activity (Mian et al. 2008). Fungi produce acid proteinases involved in formation of $\mathrm{NH}_{4}^{+}$and are active at $\mathrm{pH} 5$ (Myrold and Bottomley 2008). Visual observations of mycelia growth support the presence of fungi in the current study. Given that significant quantities of both $\mathrm{NH}_{4}^{+}-\mathrm{N}$ and $\mathrm{NO}_{3}^{-}-\mathrm{N}$ were present, the mineralization of $\mathrm{N}$ was based on the SMN content rather than $\mathrm{NO}_{3}^{-}-\mathrm{N}$ alone.

The effects of treatment, day, and treatment $\times$ day interaction were significant for net $\mathrm{N}$ mineralization $(P<0.0001)$. The interaction signifies that the treatments produced different effects on $\mathrm{N}$ mineralization over time, likely a reflection of $\mathrm{N}$ immobilization vs. mineralization rates in different treatments. Because there was a significant interaction, a model was fitted to data from each treatment and the differences among treatments were also assessed on the $56 \mathrm{~d}$ of incubation. 


\section{Net Nitrogen Mineralization}

By $56 \mathrm{~d}$, broccoli residue alone resulted in the net mineralization of $67.0 \mathrm{mg} \mathrm{N} \mathrm{kg}^{-1}$, and the addition of fertilizer to broccoli residue did not significantly alter net $\mathrm{N}$ mineralization (Table 2). Therefore, the quantity of $\mathrm{N}$ released from broccoli residue appears to be independent of the initial SMN levels. Based on total $\mathrm{N}$ in broccoli residue, $37 \%$ was apparently mineralized by 56 d. Similarly, De Neve and Hofman (1996) studied apparent $\mathrm{N}$ mineralization from broccoli residue parts (leaf blades, upper stem and lower stem) which ranged from $\approx 35$ to $60 \%$ of total $\mathrm{N}$, after $105 \mathrm{~d}$ of incubation. The sharpest rise in apparent broccoli $\mathrm{N}$ mineralization was in the first 1 to $3 \mathrm{~d}$ (De Neve and Hofman 1996). Accordingly, by $1 \mathrm{~d}, 18 \%$ of total broccoli residue $\mathrm{N}$ was apparently released as mineral $\mathrm{N}$ in the current study.

After $56 \mathrm{~d}$, net $\mathrm{N}$ mineralization of broccoli residue alone (67.0 $\mathrm{mg} \mathrm{N} \mathrm{kg}^{-1}$ ) was significantly lowered by the amendments of wheat straw, yard waste, and used cooking oil by $16.9,12.3$, and $86.0 \mathrm{mg} \mathrm{N} \mathrm{kg}-1$, respectively (Fig. 1, Table 2). The effect of OCA on net immobilization of broccoli residue-derived $\mathrm{N}$ followed the order of: used cooking oil $>$ wheat straw $=$ yard waste, which corresponds to the trend from highest to lowest $\mathrm{C}: \mathrm{N}$ ratio (Table 1) and the quantities of $\mathrm{C}$ added in each OCA. The order may therefore be a function of the organic carbon's decomposability.

The fertilizer alone treatment had a SMN concentration of $79.8 \mathrm{mg} \mathrm{kg}^{-1}$ by $56 \mathrm{~d}$. Net $\mathrm{N}$ mineralization after $56 \mathrm{~d}$ in each fertilizer-derived $\mathrm{N}$ with OCA treatment was lowered relative to the fertilizer alone by 28.3, 9.9, and $66.2 \mathrm{mg} \mathrm{N} \mathrm{kg}^{-1}$ with wheat straw, yard waste, and used cooking oil treatments, respectively (Table 2). The effectiveness of OCA to immobilize fertilizer-derived $\mathrm{N}$ followed the order of: used cooking oil $>$ wheat straw $>$ yard waste, similar to the order observed with broccoli residue-derived $\mathrm{N}$ with $\mathrm{OCA}$. Hence, the largest amount of $\mathrm{N}$ immobilization resulted with used cooking oil application, whether $\mathrm{N}$ was derived from broccoli residue or fertilizer.

When the source of $\mathrm{N}$ was derived from broccoli residue compared with fertilizer, net $\mathrm{N}$ immobilization was similar for the wheat straw and yard waste treatments yet immobilization was higher in the used cooking oil treatment (Table 2). Compared with fertilizer, it appears that broccoli residue facilitated a synergistic effect on net $\mathrm{N}$ immobilization with used cooking oil, probably due to stimulation of microbial activity by the broccoli residue and/or microbial luxury $\mathrm{N}$ consumption. Mary et al. (1996) suggested that differences in microbial $\mathrm{N}$ assimilation exist, and were likely due to the type of decomposing microflora. Thus, it was possible that the suggested synergistic effect on $\mathrm{N}$ immobilization occurred for used cooking oil but not for wheat straw or yard waste due to the different microflora involved in primary decomposition of each OCA.

Although the result of net $\mathrm{N}$ immobilization with OCA application was consistent with other incubation studies, the level of $\mathrm{N}$ immobilization appears lower than previous research. Net $\mathrm{N}$ immobilization was 53-65, 20-50, and $200 \mathrm{mg} \mathrm{N} \mathrm{kg}^{-1}$ after the addition of maize straw (Recous et al. 1995), compost (Hartz and Giannini 1998), and used cooking oil (Plante and Voroney 1998), respectively.

Net $\mathrm{N}$ mineralization data were fitted to a first-order exponential model (Table 3). Unamended and $\mathrm{N}$ fertilizer alone treatments released 25.7 and $21.4 \mathrm{mg} \mathrm{N} \mathrm{kg}^{-1}$ throughout incubation, according to the equations $\mathrm{SMN}=56.8\left(1-\exp ^{-1.762(t)}\right)$ and $74.8\left(1-\exp ^{-1.389(t)}\right)$, respectively. The present estimated $k$ coefficients for net $\mathrm{N}$ mineralization were 0.31 and 0.14 from broccoli residue alone or broccoli residue with fertilizer $\mathrm{N}$, respectively (Table 3 ). Previous research found broccoli residue mineralization fitted a similar first-order kinetics model, where rate constant values for separate broccoli plant parts (leaf blades, upper stem, lower stem) ranged from 0.635 to 1.697 (De Neve and Hofman 1996). The discrepancy between De Neve and Hofman (1996) and our $k$ constants may be due to fresh residue incorporation in non-air-dried soil compared with dry residue incorporation in dried and re-wetted soil, respectively. Drying soil retards the decomposition of added materials (Magid et al. 1999), thus supporting the slower decomposition indicated by the lower rate constants in

Table 2. The effect of organic carbon amendment with broccoli residue-derived $\mathrm{N}$ or fertilizer-derived $\mathrm{N}$ on net $\mathrm{N}$ and $\mathrm{C}$ mineralization at 4 or $56 \mathrm{~d}$ of incubation

\begin{tabular}{|c|c|c|c|c|c|c|}
\hline \multirow[b]{2}{*}{ Amendment } & \multicolumn{2}{|c|}{$\begin{array}{l}\text { Net } \mathrm{C} \text { mineralization rate at } 4 \mathrm{~d} \\
\quad\left(\mathrm{mg} \mathrm{C} \mathrm{kg}^{-1}{\left.\mathrm{dry} \mathrm{soil} \mathrm{d}^{-1}\right)}\right.\end{array}$} & \multicolumn{2}{|c|}{$\begin{array}{l}\text { Net } \mathrm{N} \text { mineralization at } 56 \mathrm{~d} \\
(\mathrm{mg} \mathrm{N} \mathrm{kg}-1 \text { dry soil })\end{array}$} & \multicolumn{2}{|c|}{$\begin{array}{l}\text { Net } \mathrm{C} \text { mineralization at } 56 \mathrm{~d} \\
(\mathrm{mg} \mathrm{C} \mathrm{kg}-1 \text { dry soil })\end{array}$} \\
\hline & $\mathrm{NH}_{4} \mathrm{NO}_{3}$ & Broccoli residue & $\mathrm{NH}_{4} \mathrm{NO}_{3}$ & Broccoli residue & $\mathrm{NH}_{4} \mathrm{NO}_{3}$ & Broccoli residue \\
\hline Broccoli residue & $10.6 b$ & $10.0 b$ & $73.5 a$ & $67.0 a$ & $68.5 c$ & $66.2 c$ \\
\hline Wheat straw & $<0.1 d$ & $<0.1 d$ & $-28.3 c$ & $-16.9 b c$ & $25.1 d$ & $33.6 d$ \\
\hline Yard waste & $<0.1 d$ & $1.4 c$ & $-9.9 b$ & $-12.3 b$ & $4.0 e$ & $20.7 d$ \\
\hline Used cooking oil & $12.2 a$ & $11.8 a$ & $-66.2 d$ & $-86.0 e$ & $155 b$ & $176 a$ \\
\hline Standard error & \multicolumn{2}{|c|}{0.35} & \multicolumn{2}{|c|}{4.57} & \multicolumn{2}{|c|}{5.52} \\
\hline
\end{tabular}

$a-e$ For each mineralization section, means followed by the same letter were not significantly different according to an LSD test of simple treatment effects. 

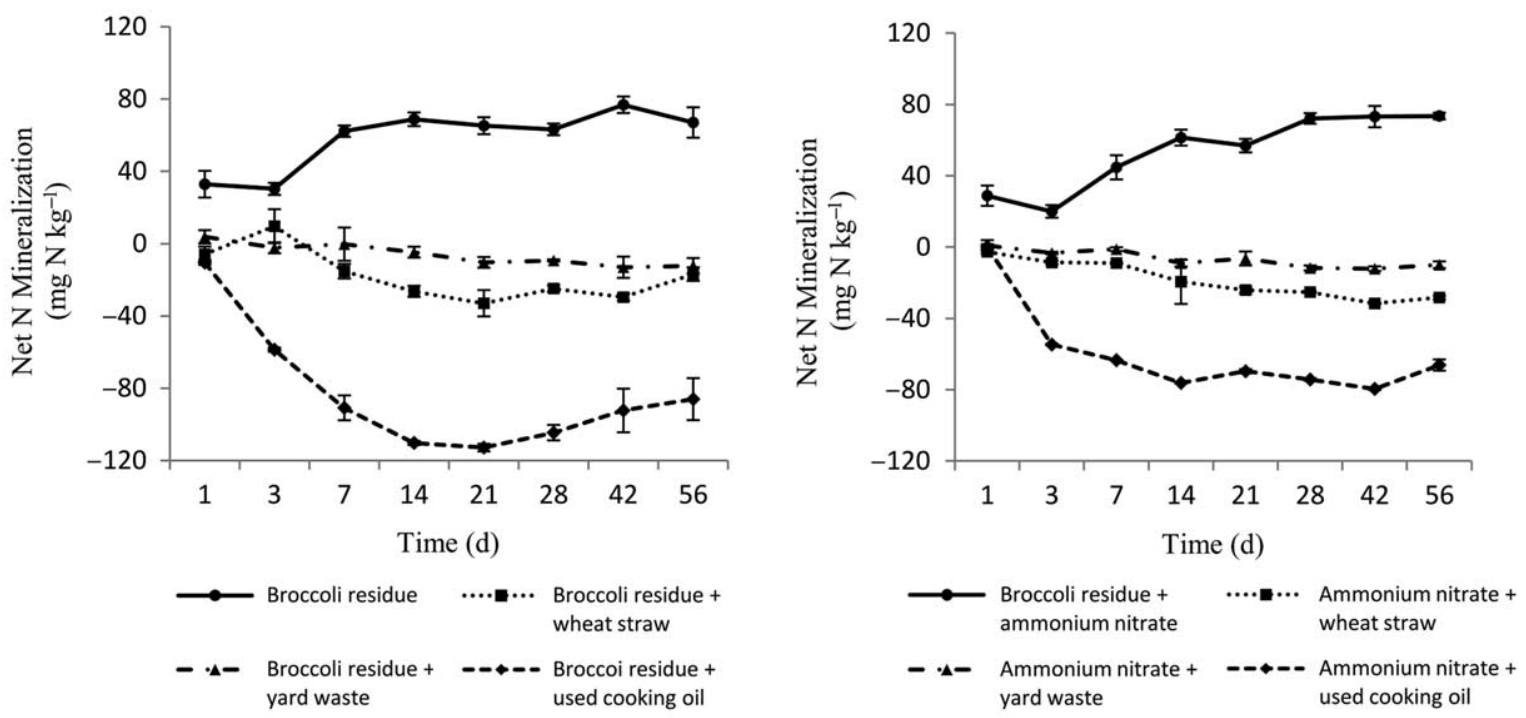

Fig. 1. Net $\mathrm{N}$ mineralization ( $\mathrm{mg} \mathrm{N} \mathrm{kg}^{-1}$ dry soil) as affected by organic carbon amendment with broccoli residue-derived $\mathrm{N}$ (left) or fertilizer-derived N (right), during the 56-d incubation. Data points represent the mean of observed values $(n=4)$ and bars represent the standard error of the mean but may be smaller than the symbols.

the present study compared with De Neve and Hofman (1996).

Positive net $\mathrm{N}$ mineralization occurred in the broccoli residue alone and broccoli residue with fertilizer $\mathrm{N}$, while negative net $\mathrm{N}$ mineralization, indicating $\mathrm{N}$ immobilization, occurred in broccoli residue-derived $\mathrm{N}$ and fertilizer-derived $\mathrm{N}$ with each OCA (Fig. 1; Table 3). Therefore, the overall trend in net $\mathrm{N}$ mineralization with OCA was negative whether $\mathrm{N}$ was derived from broccoli residue or fertilizer. Similar to the patterns for net $\mathrm{N}$ mineralization in this study, previous research demonstrated net $\mathrm{N}$ immobilization with application of wheat straw (Jawson and Elliot 1986; Mary et al. 1996; Bending and Turner 1999; Henriksen and Breland 1999), net immobilization of $39 \mathrm{mg} \mathrm{N} \mathrm{g}^{-1} \mathrm{C}$ added as maize straw
(Recous et al. 1995), 1.2 to $5 \mathrm{mg} \mathrm{N}$ net immobilized per month after the application of compost yard waste (Claassen and Carey 2004), and rapid N immobilization within 2 to $4 \mathrm{~d}$ of application of used cooking oil (Plante and Voroney 1998).

In the broccoli residue-derived $\mathrm{N}$ with used cooking oil treatment, net $\mathrm{N}$ mineralization increased after $21 \mathrm{~d}$ (Fig. 1) suggesting re-mineralization of $\mathrm{N}$ from microbial biomass. Although the exponential model significantly fitted the data from $1 \mathrm{~d}$ to $56 \mathrm{~d}$ for the broccoli residuederived $\mathrm{N}$ with used cooking oil treatment (Table 3), a linear model of: $y=-127+0.76(t) \quad(y=$ net SMN, $t=$ incubation day), significantly fitted the data from $21 \mathrm{~d}$ to $56 \mathrm{~d}\left(r^{2}=0.31, P=0.0242\right)$. Thus, $\mathrm{N}$ remineralization occurred after $21 \mathrm{~d}$. It was possible that

Table 3. Effect of organic carbon amendment with broccoli residue-derived $\mathrm{N}$ or fertilizer-derived $\mathrm{N}$ on net $\mathrm{N}$ mineralization in the $56 \mathrm{~d}$ incubation

\begin{tabular}{|c|c|c|c|c|c|c|}
\hline \multirow[b]{3}{*}{$\mathrm{N}$ source } & \multirow[b]{3}{*}{$\mathrm{C}$ amendment } & \multicolumn{5}{|c|}{ Model parameters ${ }^{\mathbf{z}}$} \\
\hline & & \multicolumn{2}{|c|}{--------------------------- $A$-------------------------- } & \multicolumn{2}{|c|}{-----------------------k } & \multirow[b]{2}{*}{ Pseudo $R^{2}$} \\
\hline & & Value & $95 \% \mathrm{CL}^{\mathrm{y}}$ & Value & $95 \% \mathrm{CL}^{\mathrm{y}}$ & \\
\hline Broccoli residue & & 68.3 & 62.7 to 73.9 & 0.31 & 0.18 to 0.43 & 0.62 \\
\hline Broccoli residue & Wheat straw & -26.9 & -34.9 to -18.8 & 0.11 & -0.010 to 0.23 & 0.45 \\
\hline Broccoli residue & Yard waste & -16.4 & -39.8 to 7.0 & 0.03 & -0.050 to 0.11 & 0.29 \\
\hline Broccoli residue & Used cooking oil & -102 & -109 to -94.4 & 0.27 & 0.18 to 0.37 & 0.81 \\
\hline $\mathrm{NH}_{4} \mathrm{NO}_{3}$ & Broccoli residue & 70.6 & 63.8 to 77.5 & 0.14 & 0.090 to 0.20 & 0.75 \\
\hline $\mathrm{NH}_{4} \mathrm{NO}_{3}$ & Wheat straw & -29.7 & -36.0 to -23.5 & 0.10 & 0.030 to 0.17 & 0.56 \\
\hline $\mathrm{NH}_{4} \mathrm{NO}_{3}$ & Yard waste & -11.9 & -16.5 to -7.30 & 0.06 & -0.00040 to 0.12 & 0.50 \\
\hline $\mathrm{NH}_{4} \mathrm{NO}_{3}$ & Used cooking oil & -73.7 & -78.0 to -69.3 & 0.30 & 0.21 to 0.38 & 0.89 \\
\hline
\end{tabular}

${ }^{\mathbf{z}}$ Fitted to a first order exponential model $\mathrm{y}=A\left(1-\exp ^{-k(t)}\right),(\mathrm{y}=$ net $\mathrm{SMN}, A=$ coefficient, $k=$ rate constant, $t=$ day $)$. All models presented were significant at $P<0.0001$.

${ }^{y}$ Upper and lower confidence limits. 
a reduced quantity of easily oxidizable $\mathrm{C}$ or available $\mathrm{N}$ remained after $21 \mathrm{~d}$, which triggered microbial death and turnover in the broccoli residue-derived $\mathrm{N}$ with the used cooking oil treatment. The pattern of $\mathrm{N}$ immobilization followed by re-mineralization with cooking oil was consistent with other laboratory (Smith 1974) and field (Rashid and Voroney 2003) studies. If the period of $\mathrm{N}$ immobilization coincides with periods of high risk for $\mathrm{N}$ losses in the field, a reduction in $\mathrm{N}$ losses may result. Future research should use field studies to investigate the effects of applying organic $\mathrm{C}$ and assess $\mathrm{N}$ losses after cole crop harvest and effects on subsequent crop production.

\section{Net Carbon Mineralization}

The effects of treatment, day, and treatment $\times$ day interaction were significant $(P<0.0001)$ for net cumulative $\mathrm{C}$ mineralization. The interaction signifies that the treatments produced different effects on net $\mathrm{C}$ mineralization over time, likely a reflection of the differences in microbial activity with different treatments. Because there was a significant interaction, analysis focused on the 56-d net $\mathrm{C}$ mineralization measures, as well as the peak rates of net $\mathrm{C}$ mineralization. Unamended and fertilizer-alone treatments had negligible $\mathrm{C}$ mineralization over the study, (3.45 and $0.82 \mathrm{mg} \mathrm{C} \mathrm{kg}^{-1}$, respectively), suggesting low levels of microbial activity due to the lack of readily mineralizable $\mathrm{C}$.

The effect of OCAs on net $\mathrm{C}$ mineralization followed the order: used cooking oil $>$ wheat straw $=$ yard waste with broccoli residue-derived $\mathrm{N}$, and the order: used cooking oil $>$ wheat straw $>$ yard waste with fertilizerderived N (Fig. 2; Table 2). Amendments were added at an equivalent field rate of $5 \mathrm{Mg} \mathrm{ha}^{-1}$, which resulted in
C loading rates of $1.2,0.9$, and $1.5 \mathrm{~g} \mathrm{C} \mathrm{kg}^{-1}$ soil for wheat straw, yard waste, and used cooking oil, respectively. When net $\mathrm{C}$ mineralization on $56 \mathrm{~d}$ was expressed as a proportion of $\mathrm{C}$ loading rates, OCAs with broccoli residue-derived $\mathrm{N}$ had net $\mathrm{C}$ mineralization of 118,28 , and $23 \mathrm{mg} \mathrm{C} \mathrm{kg}^{-1}$, and with fertilizer-derived $\mathrm{N}$ had 104 , 21 , and $4.4 \mathrm{mg} \mathrm{C} \mathrm{kg}^{-1}$ from used cooking oil, wheat straw, and yard waste, respectively. Thus, the order of net $\mathrm{C}$ mineralization of OCAs was not influenced by the slightly different $\mathrm{C}$ loading rates but reflects the amendment's decomposability, and corresponds to the order of effect on $\mathrm{N}$ immobilization noted earlier, as well as the descending trend for $\mathrm{C}: \mathrm{N}$ ratio (Table 1). Based on the $\mathrm{C}$ loading rates, the $\mathrm{CO}_{2}$ emitted, and the assumption that microbes have a $\mathrm{C}$ assimilation efficiency of approximately $30 \%$, wheat straw, yard waste, and used cooking oil were up to 4,3 , and $16 \%$ decomposed after 8 wk of incubation with broccoli crop residue.

In soil amended with broccoli residue alone, the rate of peak net $\mathrm{C}$ mineralization occurred at $4 \mathrm{~d}$ with 10.0 $\mathrm{mg} \mathrm{C} \mathrm{kg}{ }^{-1} \mathrm{~d}^{-1}$ and was not significantly different from broccoli residue with fertilizer (Table 2). When used cooking oil decomposed with broccoli residue-derived $\mathrm{N}$ or fertilizer-derived $\mathrm{N}$, peak net $\mathrm{C}$ mineralization also occurred at $4 \mathrm{~d}$, synchronous with that of broccoli residue alone (Table 2). Relative to broccoli residue or used cooking oil, lower rates of net $\mathrm{C}$ mineralization occurred in wheat straw and yard waste treatments with peaks after $7 \mathrm{~d}$ (Table 2). Therefore, used cooking oil decomposed more rapidly than wheat straw and yard waste. The interpretation of results was not different if the peak rates were analyzed at $4 \mathrm{~d}$ or after $7 \mathrm{~d}$ for wheat straw and yard waste. It should be noted that peak level of net $\mathrm{N}$ immobilization in used cooking oil treatment
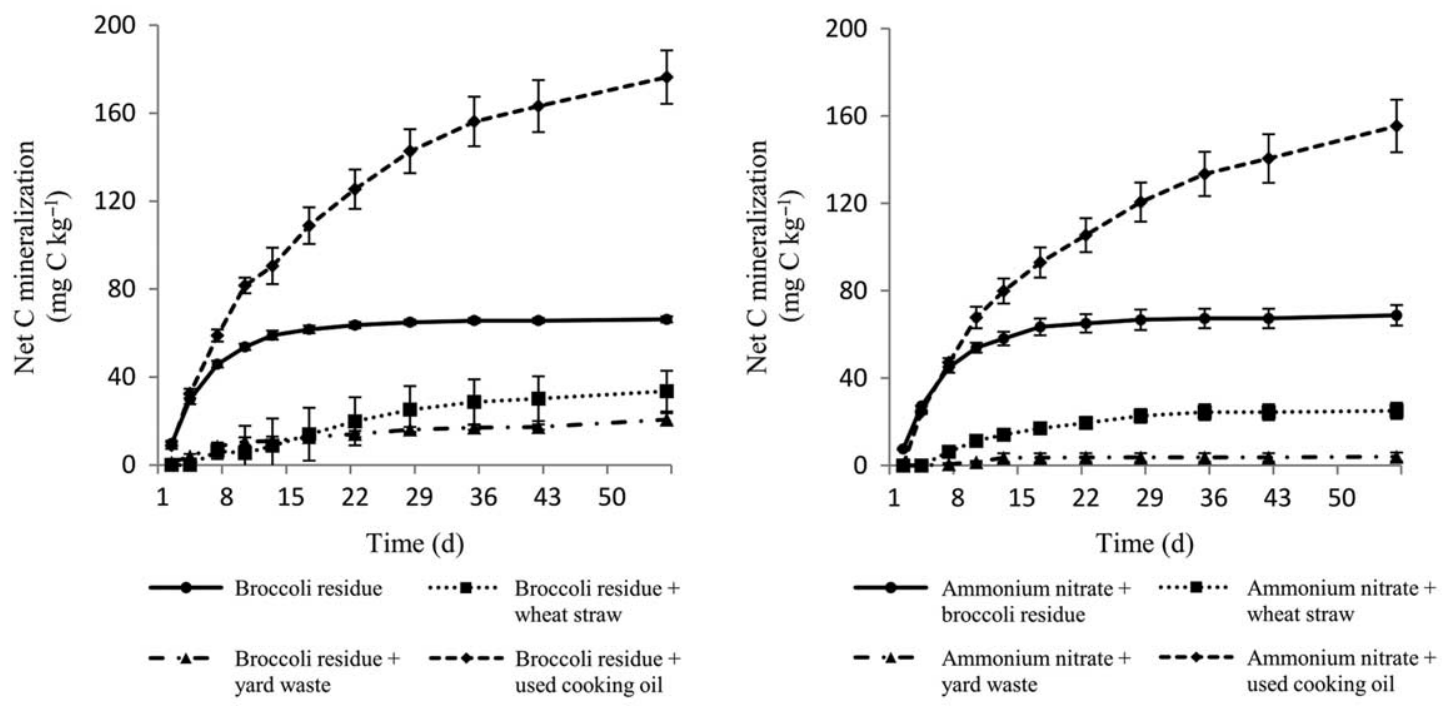

Fig. 2. Net cumulative $\mathrm{C}$ mineralization $\left(\mathrm{mg} \mathrm{C} \mathrm{kg}^{-1}\right.$ dry soil) as affected by organic carbon amendment with broccoli residuederived N (left) or fertilizer-derived N (right), during the 56-d incubation. Data points represent the mean of observed values $(n=4)$ and bars represent the standard error of the mean but may be smaller than the symbols. 
coincided with peak rate of net $\mathrm{C}$ mineralization, akin to other research (Plante and Voroney 1998). It therefore appears that used cooking oil, compared with the other OCAs, stimulated earlier microbial activity, which was most synchronous to that of broccoli residue.

Similarly, Jawson and Elliot (1986) found peak $\mathrm{CO}_{2}$ evolution after $6 \mathrm{~d}$ of incubation of wheat straw added to soil, and Plante and Voroney (1998) found peak C mineralization rate near $4 \mathrm{~d}$ for decomposition of canola oil. Peak $\mathrm{C}$ mineralization rates from the decomposition of canola oil were 35 or $52 \mathrm{mg} \mathrm{C} \mathrm{kg}^{-1}$ soil h${ }^{-1}$ (Plante and Voroney 1998), much higher than that of the present study. The discrepancy may be related to a lower microbial population establishment due to the soil drying pre-treatment, or the higher $\mathrm{C}$ loading rates of 6 and $13 \mathrm{~g} \mathrm{C} \mathrm{kg}^{-1}$ soil in Plante and Voroney's study (1998) compared with $1.5 \mathrm{~g} \mathrm{C} \mathrm{kg}^{-1}$ soil in our study. Plante and Voroney (1998) also found a higher extent of decomposition from oily food waste (36 to $40 \%$ ) after 4 wk of incubation, compared with the current study.

The yard waste and used cooking oil treatments had a significantly greater quantity of net $\mathrm{C}$ mineralization when supplied with $\mathrm{N}$ derived from broccoli residue compared with fertilizer (Table 2). The enhanced net $\mathrm{C}$ mineralization with broccoli residue-derived $\mathrm{N}$ with used cooking oil supports the synergistic effect of broccoli residue on net $\mathrm{N}$ immobilization, suggested earlier. Although there was no enhanced $\mathrm{N}$ immobilization for yard waste with broccoli residue-derived $\mathrm{N}$ compared with yard waste with fertilizer-derived $\mathrm{N}$, the net $\mathrm{C}$ mineralization data suggests that broccoli residue enhanced microbial activity during decomposition of yard waste, relative to fertilizer (Table 2). Considering that yard waste is composed of more structural components, such as lignin, it likely had a greater quantity of less easily oxidizable $\mathrm{C}$ than the other OCAs. Thus, the addition of readily decomposable broccoli residue may have stimulated microbial growth, consequently promoting $\mathrm{C}$ mineralization of an otherwise more recalcitrant material, yard waste.

\section{Overall Nitrogen and Carbon Dynamics}

The quantity and rate of net $\mathrm{N}$ and $\mathrm{C}$ mineralization are dependent on the type of substrate, its $\mathrm{C}: \mathrm{N}$ ratio, and quantity of $\mathrm{C}$ applied. In the present study, used cooking oil had the highest $\mathrm{C}: \mathrm{N}$ ratio (Table 1), and the most rapid decomposition. It is expected that the nature and particle size of each OCA influences $\mathrm{N}$ dynamics. Bending and Turner (1999) found that increasing surface area available for colonization induces earlier utilization of substrate by soil microbes. Liquid used cooking oil would have greater exposed surface area in soil compared with either solid wheat straw or yard waste, which may have contributed to earlier microbial activity in treatments containing used cooking oil compared with the other OCAs (Table 2). Another possible explanation for the differences in $\mathrm{N}$ and $\mathrm{C}$ dynamics resulting from different OCA treatments may be that different types of microflora were involved in the primary decomposition of each substrate (Mary et al. 1996).

\section{CONCLUSION}

Broccoli residue appears to have had a synergistic effect on $\mathrm{N}$ immobilization with used cooking oil, and enhanced net $\mathrm{C}$ mineralization of both yard waste and used cooking oil. The synergistic effect suggests that a greater capacity of $\mathrm{N}$ immobilization and microbial activity may result when the organic carbon is incorporated with broccoli residue. Nitrogen re-mineralization of used cooking oil with broccoli residue should be explored with field studies to predict an optimal time of used cooking oil application, the potential to minimize postharvest $\mathrm{N}$ losses, and assess latent effects on subsequent crops. Based on the presented results, field experiments are recommended to examine wheat straw, yard waste, or used cooking oil as a management practice for reducing post-harvest $\mathrm{N}$ losses in cole crop production. Used cooking oil presents the most promise due to greater levels of net $\mathrm{N}$ immobilization and the synchronous peak net $\mathrm{C}$ mineralization with broccoli residue.

\section{ACKNOWLEDGEMENTS}

Financial support by the Ontario Ministry of Agriculture, Food and Rural Affairs (OMAFRA) New Directions Program is greatly acknowledged, as well as contributions of Mike Zink and Jonathan Gorham.

Addiscott, T. M., Whitmore, A. P. and Powlson, D. S. 1991. Farming, fertilizers and the nitrate problem. CAB International, Wallingford, UK. $170 \mathrm{pp}$.

Amlinger, F., Götz, B., Dreher, P., Geszti, J. and Weissteiner, C. 2003. Nitrogen in biowaste and yard waste compost: dynamics of mobilisation and availability - A review. Eur. J. Soil Sci. 39: 107-116.

Avrahami, S., Liesack, W. and Conrad, R. 2003. Effects of temperature and fertilizer on activity and community structure of soil ammonia oxidizers. Environ. Microbiol. 5: 691-705.

Bartlett, R. and James, B. 1980. Studying dried, stored soil samples - some pitfalls. Soil Sci. Soc. Am. J. 44: 721-724.

Bakker, C. J., Swanton, C. J. and McKeown, A. W. 2009a. Broccoli growth in response to increasing rates of pre-plant nitrogen. II. Dry matter and nitrogen accumulation. Can. J. Plant Sci. 89: 539-548.

Bakker, C. J., Swanton, C. J. and McKeown, A. W. 2009b. Broccoli growth in response to increasing rates of pre-plant nitrogen. I. Yield and quality. Can. J. Plant Sci. 89: 527-537. Bending, G. D. and Turner, M. K. 1999. Interaction of biochemical quality and particle size of crop residues and its effects on the microbial biomass and nitrogen dynamics following incorporation into soil. Biol. Fertil. Soils. 29: 319-327.

Birch, H. F. 1959. Further observations on humus decomposition and nitrification. Plant Soil. 11: 262-286.

Blagodatsky, S. and Yevdokimov, I. 1998. Extractability of microbial $\mathrm{N}$ as influenced by $\mathrm{C}: \mathrm{N}$ ratio in the flush after drying or fumigation. Biol. Fertil. Soils. 28: 5-11.

Bowley, S. R. 2008. A hitchhiker's guide to statistics in plant biology. 2nd ed. Any Old Subject Books, Guelph, ON. 266 pp. 
Carter, M. R. and Gregorich, E. G. 2008. Soil sampling and methods of analysis. 2nd ed. CRC, Boca Ratan, FL. 1224 pp. Claassen, V. P. and Carey, J. L. 2004. Regeneration of nitrogen fertility in disturbed soils using composts. Compost Sci. Util. 12: 145-152.

De Neve, S. and Hofman, G. 1996. Modelling of N mineralization of vegetable crop residues during laboratory incubations. Soil Biol. Biochem. 28: 1451-1457.

De Neve, S., Pannier, J. and Hofman, G. 1996. Temperature effects on $\mathrm{C}$ - and $\mathrm{N}$-mineralization from vegetable crop residues. Plant Soil. 181: 25-30.

Efron, B. 1978. Regression and ANOVA with zero-one data: Measures of residual variation. J. Am. Stat. Assoc. 73: 113-121.

Everaarts, A. P. 1993. Strategies to improve the efficiency of nitrogen fertilizer use in the cultivation of Brassica vegetables. Acta Hortic. 339: 161-173.

Everaarts, A. P. and De Willigen, P. 1999a. The effect of the rate and method of nitrogen application on nitrogen uptake and utilization by broccoli (Brassica oleracea var. italica). Neth. J. Agric. Sci. 47: 201-214.

Everaarts, A. P. and De Willigen, P. 1999b. The effect of nitrogen and the method of application on yield and quality of broccoli. Neth. J. Agric. Sci. 47: 123-133.

Fu, M. H., Xu, X. C. and Tabatabai, M. A. 1987. Effect of $\mathrm{pH}$ on nitrogen mineralization in crop-residue-treated soils. Biol. Fertil. Soils. 5: 115-119.

Hans-Werner, O., Neu, A. and Werner, W. 2004. Soil N transformations after application of ${ }^{15} \mathrm{~N}$-labeled biomass in incubation experiments with repeated soil drying and rewetting. J. Plant Nutr. Soil Sci. 167: 147-152.

Hart, S. C., DeLuca, T. H., Newman, G. S., MacKenzie, M. D. and Boyle, S. I. 2005. Post-fire vegetative dynamics as drivers of microbial community structure and function in forest soils. For. Ecol. Manage. 220: 166-184.

Hartz, T. K. and Giannini, C. 1998. Duration of composting of yard wastes affects both physical and chemical characteristics of compost and plant growth. HortScience 33: 1192-1196.

Hasson, A. M., Hassaballah, T., Hussain, R. and Abbass, L. 1987. Effect of solar soil sterilization on nitrification in soil. J. Plant Nutr. 10: 1805-1809.

Henriksen, T. M. and Breland, T. A. 1999. Nitrogen availability effects on carbon mineralization, fungal and bacterial growth, and enzyme activities during decomposition of wheat straw in soil. Soil Biol. Biochem. 31: 1121-1134.

Jawson, M. D. and Elliot, L. F. 1986. Carbon and nitrogen transformations during wheat straw and root decomposition. Soil Biol. Biochem. 18: 15-22.

Kaewpradit, W., Toomsan, B., Cadisch, G., Vityakon, P., Limpinuntana, V., Saenjan, P., Jogloy, S. and Patanothai, A. 2009. Mixing groundnut residues and rice straw to improve rice yield and $\mathrm{N}$ use efficiency. Field Crop Res. 110: 130-138. Littell, R. C., Stroup, W. W. and Freund, R. J. 2002. SAS for linear models. 4th ed. SAS Institute, Inc., Cary, NC. 466 pp. Magid, J., Kjaergaarda, C., Gorissen, A. and Kuikmanb, P. J. 1999. Drying and rewetting of a loamy sand soil did not increase the turnover of native organic matter, but retarded the decomposition of added ${ }^{14} \mathrm{C}$-labelled plant material. Soil Biol. Biochem. 31: 595-602.
Mary, B., Recous, S., Darwis, D. and Robin, D. 1996. Interaction between decomposition of plant residues and $\mathrm{N}$ cycling in soil. Plant Soil 181: 71-82.

Maynard, D. G., Kalra, Y. P. and Crumbaugh, J. A. 2008. Nitrate and exchangeable ammonium nitrogen. Pages $71-80$ in M. R. Carter and E. G. Gregorich, eds. Soil sampling and methods of analysis. 2nd ed. CRC, Boca Raton, FL.

Mian, I. A., Riaz, M. and Cresser, M. S. 2008. What controls the nitrate flush when air dried soils are rewetted? Chem. Ecol. 24: 259-267.

Myers, R. J. K. 1975. Temperature effects on ammonification and nitrification in a tropical soil. Soil Biol. Biochem. 7: 83-86. Myrold, D. D. and Bottomley, P. J. 2008. Nitrogen mineralization and immobilization. Pages $157-168$ in J. S. Schepersm and W. Raun, eds. Nitrogen in agricultural systems. ASA, CSSA, SSSA, Madison, WI.

Neetson, J. J., Booij, R. and Whitmore, A. P. 1999. A review on sustainable nitrogen management in intensive vegetable production systems. Acta Hortic. 506: 17-28.

Norton, J. M. 2008. Nitrification in agricultural soils. Pages 173-1199 in J. S. Schepersm and W. Raun eds. Nitrogen in agricultural systems. ASA, CSSA, SSSA, Madison, WI.

Paul, E. A. and Clark F. E. 1996. Soil microbiology and biochemistry. 2nd ed. Academic Press, San Diego, CA. 340 pp. Plante, A. F. and Voroney, R. P. 1998. Decomposition of land applied oily food waste and associated changes in soil aggregate stability. J. Environ. Qual. 27: 395-402.

Rashid, M. T. and Voroney, R. P. 2003. Recycling soil nitrate nitrogen by amending agricultural lands with oily food waste. J. Environ. Qual. 32: 1881-1886.

Rashid, M. T. and Voroney, R. P. 2004. Land application of oily food waste and corn production on amended soils. Agron. J. 96: 997-1004.

Recous, S., Robin, D. D. and Mary, B. 1995. Soil inorganic N availability: Effect on maize residue decomposition. Soil Biol. Biochem. 27: 1529-1538.

Rutherford, P. M., McGill, W. B., Arocena, J. M. and Figueiredo, C. T. 2008. Total nitrogen. Pages 239-250 in M. R. Carter and E. G. Gregorich, eds. Soil sampling and methods of analysis. 2nd ed. CRC, Boca Raton, FL.

Saxton, K. E., Rawls, W. J., Romberger, J. S. and Papendick, R. I. 1986. Estimating generalized soil-water characteristics from texture. Soil Sci. Soc. Am. J. 50: 1031-1036.

Smith, J. H. 1974. Decomposition in soil of waste cooking oil used in potato processing. J. Environ. Qual. 3: 279-281.

Thompson, T. L., Doerge, T. A. and Godin, R. E. 2002. Subsurface drip irrigation and fertigation of broccoli: I. Yield, quality, and nitrogen uptake. Soil Sci. Soc. Am. J. 66: 186-192. Thompson, T. L., White, S. A., Walworth, J. and Sower, G. J. 2003. Fertigation frequency of subsurface drip-irrigated broccoli. Soil Sci. Soc. Am. J. 67: 910-918.

Yoldas, F., Ceylan, S., Yagmur, B. and Mordogan, N. 2008. Effects of nitrogen fertilizer on yield quality and nutrient content in broccoli. J. Plant Nutr. 31: 1333-1343.

Zebarth, B. J., Bowen, P. A. and Toivonen, P. M. A. 1995. Influence of nitrogen fertilization on broccoli yield, nitrogen accumulation and apparent fertilizer-nitrogen recovery. Can. J. Plant Sci. 75: 717-725. 